\title{
Online Learning Experiences of Students with Deaf and Speech Disabilities During Covid-19 Pandemic
}

\author{
Astri Hanjarwati ${ }^{1}$, Aninda Aji Siwi ${ }^{2}$ \\ \{astri.hanjarwati@uin-suka.ac.id ${ }^{1}$, aninda.siwi@uin-suka.ac.id²
}

Sociology Departement, Faculty of Social and Humaniora, UIN Sunan Kalijaga Yogyakarta ${ }^{1}$, English Department, Faculty of Adab and Cultural Sciences, UIN Sunan Kalijaga Yogyakarta ${ }^{2}$

\begin{abstract}
Since Covid-19 pandemic hit Indonesia in early 2020, the government has issued policies to minimize the spreading. One of the policies is School from Home. This policy was then adapted by UIN Sunan Kalijaga to carry online learning to all students. UIN Sunan Kalijaga, as an inclusive university, has students with disabilities, of course, has to make a lot of modifications related to the platform used in learning. Based on this background, this study aims to explore the online learning experiences of deaf and speech-disabled students related to barriers and adaptations in adjusting the learning. This is a case study research method with interviews to 15 deaf and speech-disabled students of class 2017, 2018 and 2019. This research was carried out after deaf and speechdisabled students done online learning for 2 semesters. The theory used is the AGIL theory. There are four absolute requirements in working the society; Adaptation, Goal, Attainment, Integration, and Latency. The results shows that the obstacles are at the beginning of the implementation of online learning. The lecturers used unfriendly platforms that cannot be accessed by deaf and speechdisabled students. This obstacles only lasts for the first three months of lectures. Then, the next lectures already used accessible platform for deaf and speechdisabled students. The other adaptations also been made by the deaf and speechdisabled students, some of them are doing communication with the lectures, asking for help from volunteers from Difable Service Center (PLD), and asking help from classmates.
\end{abstract}

Keywords: Covid-19 Pandemic; Online Learning experiences; Deaf and Speech Disabilities; Learning Obstacles; Learning Adaptation

\section{Introduction}

The covid-19 pandemic, which began to hit Indonesia in early 2020 (Yuliana 2020), requires the government to make policies to suppress the spread of the virus. School and working from home are the implementation of one of the policies to do social distancing and also avoiding crowds (BNBP 2012; Kemenkes RI 2020; UNICEF 2020). This policy was then adapted by all institutions, including schools, universities, companies and government agencies by issuing regulations for schools and working online. Some studies have stated that policies regarding about social distancing and implementing health protocols are the right 
policies to reduce the risk of the spread of the corona virus (Bruinen de Bruin et al. 2020; Holmes et al. 2020; Williams et al. 2020).

UIN Sunan Kalijaga Yogyakarta as one of the educational institutions has implemented an emergency response policy for Covid-19 pandemic by giving instructions to the entire academic community to carry out online academic learning and academic service since March 2020 (Husein Fakhri et al 2021). The online learning was carried out without any proper preparation at first, because of the emergency response conditions. Lecturers and students did the adaptation according to the current circumstances and conditions. The platforms used at the beginning of the learning process were also minimal, such as using whatsapp group, google classroom, and UIN Sunan Kalijaga e-learning website (Ro'fah, Hanjarwati, and Suprihatiningrum 2020).

UIN Sunan Kalijaga is an inclusive university. Some classes have students with disabilities. This condition requires different modifications and adaptation of learning more than from non-disabled students. There are 112 students with the various disabilities; blind, deaf-speech, physical, mental and intellectual disabilities. The percentage is shown in Figure 1.

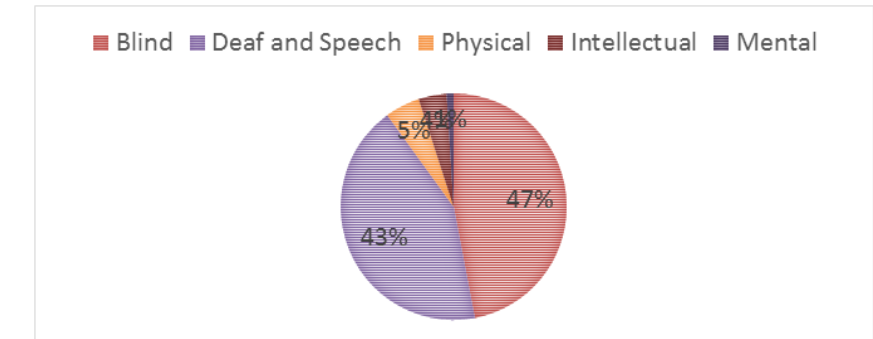

Fig. 1. The Composition of Numbers and Types of Students with Disability Sourcer: (Center of Disability Service (PLD) 2021)

Students with disabilities have several obstacles in participating online lectures, especially for the blind and deaf-speech. The blinds have difficulty in readibility of the the lecture material. The material could not be read by screen reader application. The other dificulty is that they cannot follow the discussion in the whatsapp group due to their limited ability of the screen reader applications (Maftuhin 2021). Meanwhile, the deaf-speech disabled students experienced the difficulty of no access to the video lecture material. The reason is that the videos are without the subtitles (Tegar Tio 2020). The others difficuties are just the same exprerienced by non-disabled students, like signal difficulties, quota difficulties, and also difficulties in getting books as the lecture references.

Studies on online learning during Covid-19 pandemic have been carried out by many researchers. The studies were about the obstacles in the implementation of online schools, the effectiveness of online schools, and the impacts and the implementation of online schools for students, parents, and teachers. The results shows that students, teachers, and parents experienced some difficulties in signal, the limited mastery of technology, the limited of gadget ownnership for online learning, the unlimited teachers' working hours, and the adding of parents' duties to accompany their children online school (Amalia and Sa'adah 2020; Atsani 2020; Rohaniyah et al. 2021). A similiar study also found that the concepts of elearning and e-teaching in students with disabilities play an important role in education technology applied in different educational contexts (Bjekić et al. 2014). 
Another study discusses the motivation of students, teachers and parents in implementing online schools. The results show that the students' motivation decreases during online learning. They want to join offline school as soon as possible (Cahyani, Listiana, and Larasati 2020). Other reserach reveals that teachers' motivation also decreased. The reasons are because the teachers do not have definite working hours. They must spare their time to answer parents' difficulties in accompanying their children to study at home (Basar 2021; Pratama and Mulyati 2020). A study at one of the inclusive schools stated that the obstacles in implementing online schools for students with special needs are 1) the lack of teachers' and parents' readiness in online learning, 2) the lack of skills of parents to access the internet, 3) the boredom that appears to students that make them lazy to do the online learning (N. P. Dewi 2020).

In addition to the barriers and motivations in implementing online lectures, previous research has also examined the aspects that influence the successful implementation of online schools. The success of online schools is determined by good cooperation among students, teachers, and parents (W. A. F. Dewi 2020; Purwanto et al. 2020; Wardhani and Krisnani 2020). The students are enthusiastic and disciplined in participating in the learning process, parents become facilitators in the learning process, and teachers teach and also give guidance or share knowledge to parents. Research on inclusive schools also found the colaboration between teachers and parents in educating students with disabilities empower them to be productive in learning during Covid-19 pandemic (Hamidaturrohmah and Mulyani 2020).

Studies about the learning of students with disabilities during the pandemic have also been researched. One of them is a research about the accessibility of online learning for students with disabilities. The result stated that the online learning during this pandemic using unfriendly paltforms to the disabled, especially for the blind and deaf and speech (Ro'fah et al. 2020). Another research found that education before the pandemic was not yet inclusive, so it would be better if education after the pandemic not only introduced new habbits, but also better habbits to be more inclusive and friendly to people with disabilities (Maftuhin 2021). The other study presents the Universal Design in Higher Education (UDHE) Framework as a practice that can lead to inclusive learning and students service opportunities to all participants by providing established policies, guidelines, and practices to make accessible technology, resources, and pedagogy to all students (Burgstahler 2021). According to the literature review on the implementation of online schools and lectures themes, this research is the completion of the previous research that has never been discussed about the experiences and adaptation of deaf-speech disabled students in online lectures.

This experience is related to the obstacles, conveniences, and adaptation processes that have been done by students with disabilities. The formulation of the problem is on how the process of adaptation of deaf-speech students in online lectures during Covid-19 pandemic. The method of this research is a qualitative case study, where the data collection is through indepth interviews with a structured interview guide (Creswell 2009). The interview was conducted through a google form which was then deepened by communication via whatsapp. This is done because deaf-speech students have hearing and speech impairment which make them cannot be done by telephone, video call or voice note. Data analysis was carried out by coding data, categorizing data from interviews and analyzing the findings using AGIL theory. While checking the data validity of the research is done by doing the crosscheck among the informants.

As a research guidance and also the analysis tool, the theory is Talcot Parson's structural functionalism. This theory states that society is a social system consisting of interraled 
elements and forms a balance (Holton 2015). Changes that occur in one part will bring changes to other parts. Parson suggests that there are four functions that must exist in all systems, and are better known as the AGIL scheme, they are: (1) Adaptation: The system must adapt to the environment and adapt the environment to its needs, (2) Goal Attainment: A system must defines and achieves its main objectives, (3) Integration: a system must regulate the interrelationships of its components, (4) Latency (Pattern Maintenance): a system must provide, maintain, and renew both individual motivation and cultural patterns that create and sustain that motivation (Holton 2015; Sciortino 2009).

\section{Findings and Discussion}

The obstacles experienced by deaf-speech diasabled students in online lectures are divided into two periods of time. In the first period, at the begining of 3 months in implementing the policy), the obstacles were inaccessible learning media or platforms used bu lecturers, unstable internet networks, and no assistants or sign language interpreters during lectures. The findings of this study are in accordance with those expressed by the following three informants:

1. "kuliah online sulit, tidak ada pendamping dari PLD dan video dari dosen tidak ada teksnya, jadi aku tidak paham"

2. ("online lecture is difficult, no assistant from PLD and video from the lecturer no text, $i$ cannot understand") (Deaf-Speech Student A, 2020).

3. "dirumahku sinyal jelek, pendamping PLD juga tidak ada, tapi saya maklum karena awal pandemi, semua bingung" ("in my house, the signal is bad, and also no assistant from PLD, but $i$ understand because it is the begining of pandemic, everybody get confuse") (Deaf-Speech Student B, 2020).

4. "diawal kuliah dosen pakai whatss app grup, sulit saya paham bahasa di grup, saya diam dan tidak komen" ("at the begiining of lecture, the lecturer uses whatsapp group, it is difficult to understand the language in the group, i am quiet and no comment.") (DeafSpeech Student C, 2020).

Based on interviews both via google form and whatsapp, informants stated that the inaccessible platforms refers to no subtitles videos, and also the dense of the discussion flow in whatsapp making it difficult to understand the lectures. This obstacle is considered as hard because deaf-speech disabled students have hearing impairments, barriers to understand language or sentences and speech impairment. This finding is in line with the research result conducted by Arif Maftuhin that online lectures at universities must be friendly to people with disabilities (Maftuhin 2021). Another similiar study said that at the beginning of the implementing online lecturers, learning platforms were still not accessible for blind and deafspeech disabilities (Ro'fah et al. 2020).

In the second period, entering the odd semester of 2020/2021, the obstacles are unstable internet network, boredom and low motivation to take online lectures. The unstable network problem is a problem for all students from elementary to university levels. Deaf-speech disabled students who live in difficult signal areas find it very difficult to attend lectures. Communication with lecturers or assistants from Difabel Service Center (PLD) UIN Sunan Kalijaga Yogyakarta was not run well. Besides the delayed communication, the lectures via zoom or google meet is also very constrained because of the signal. The evidences of this findings can be seen from the interviews with four informants as follows: 
"rumahku sinyal susah, bingung sendiri, kalau zoom tidak bisa ikut, dan izin dosen" ("in my house, the signal is difficult, i get confuse, i cannot attend the zoom class, i will ask permission from the lecturer") (Deaf-Speech Student C, 2020).

"saya kuliah online terkendala sinyal. Mau download video gak bisa, mau ikut zoom atau google meet gak lancar. Pendamping PLD banyak membantu mencatatkan materi ini sangat membantu" ("my online class is difficult because of the signal. I want to download the video, I can't, I want to join zoom or google meet class, but it is not running well. I get many helps from the PLD volunteer to take notes.") (Deaf-Speech Student D, 2020).

"kalau orangtua mengizinkan saya ingin kembali ke kos, karena saya kesulitan sinyal, ini menghambat kuliahku" ("If my parents give me permission, i want to go to the boarding house because i have signal difficulty, this is slow down my study.") (Deaf-Speech Student E, 2020).

"kendala kuliah online sulit sinyal, saya tidak suka kuliah online, repot sekali" ("the obstacles of online class is difficult signal, I do not like online class, it is so confusing.") (Deaf-Speech Student F, 2020).

The data above shows that online lecture require the support of technology in order the learning can be followed by students. This finding is in line with previous research which said that the obstacles of online lectures are poor signal, inadequate technology, and lack of facilities such as mobile phones and laptops or computers as the learning tools (Amalia and Sa'adah 2020; Atsani 2020; Rohaniyah et al. 2021)

In the 2020/2021 odd semester, the Difabel Service Center (PLD) of UIN Sunan Kalijaga Yogyakarta began to provide the volunteers to accompany the lecture process for deaf-speech disabled students to prevent the obstacles at the first period of implementing the online lectures recuring. In this period, lecturers have used an accessible learning platform for deafspeech students. Also in this period, the Rector has prepared better facilities and support in order to make the learning process run better compared to the even semester of 2019/2020 when in the emergency response period. At this stage there are no significant obstacles, but it is only had bad network connection and low motivation of deaf-speech students to attend the online lectures. These facts are in accordance with the following interview excerpts:

"ada pendamping pld yang membantu mencatatkan materi kuliah dan juru bahasa isyarat yang membantu menerjemah ketika presentasi" ("there is PLD assistant to help me to take lecturing notes and also a sign language interpreter to help when doin presentation.") (DeafSpeech Student A, 2020).

"dosen sudah menggunakan video yang ada teksnya, itu memudahkan. Tapi sudah bosan." ("the lecturer has already used subtitled video, this helps me. But, i get bored.") (Deaf-Speech Student G, 2020).

"kuliah semester ini lebih baik dan tidak banyak kendala tetapi sudah bosan, pengen ke kampus kuliah seperti dulu. Video sudah pakai subtitle, sudah ada pendamping dan sudah ada notetaker" ("this semester lecture is better and there is not much obstacles, but i get bored, I want to go to the campus like the old days. There is video with subtitle, there is an assistant, and there is a note taker.") (Deaf-Speech Student F, 2020).

The adaptation stages achieved by deaf-speech students in online learning process based on the reflection of AGIL theory. The first stage is Adaptation: this period lasts for approximately three months of the beginning of the lecture. Deaf-speech students adapt to inaccessible platforms and find many obstacles when joining the online lectures. At this stage, deaf-speech students find solution by communicating with lecturers, asking for help from UIN Sunan Kalijaga Yogyakarta Difabel Service Center (PLD) volunteers, and also asking for help from family and classmates. 
The second stage is achieving the goal: achieving the goal of accessible online learning is pursued by UIN Sunan Kalijaga Yogyakarta by providing training to prepare an accessible learning platform for students with disabilities. The teaching platform used by lecturers was already accessible for students with deaf-speech disabilities in the 2020/2021 odd semester.

The third stage is the integration is marked by the Rector of UIN Sunan Kalijaga to issue policies in implementing safe, comfortable and accessible online lectures for all students without any exception also for deaf-speech students. The fourth stage is the pattern maintenance: at this stage, there has not been a pattern that is able to motivate students with deaf-speech disabilities. All students are bored and decreased their motivation to study online.

\section{Conclusion}

The obstacles experienced by deaf-speech disabled students in online lectures are divided into two periods of time. In the first period (the first 3 months of policy implementation), the obstacles were inaccessible learning media or platforms used by lectures, unstable internet networks, and no assistants or sign language interpreters during lectures. The inaccessible platforms refers to no subtitles videos, and also the dense of the discussion flow in whatsapp making it difficult to understand the lectures. This obstacle is considered as hard because deafspeech disabled students have hearing impairments, barriers to understand language or sentences and speech impairment. In the second period, entering the odd semester of 2020/2021, the obstacles are unstable internet network, boredom and low motivation to take online lectures. The Difabel Service Center (PLD) of UIN Sunan Kalijaga Yogyakarta began to provide the volunteers to accompany the lecture process for deaf-speech disabled students to prevent the obstacles at the first period of implementing the online lectures recuring. In this period, lecturers have used an accessible learning platform for deaf-speech students.

The adaptation stages achieved by deaf-speech students in online learning process based on the reflection of AGIL theory are: (1) Adaptation: this period lasts for approximately three months of the beginning of the lecture. Deaf-speech students adapt to inaccessible platforms and find many obstacles when joining the online lectures. At this stage, deaf-speech students find solution by communicating with lecturers, asking for help from UIN Sunan Kalijaga Yogyakarta Difabel Service Center (PLD) volunteers, and also asking for help from family and classmates. (2) Achieving the goal: achieving the goal of accessible online learning is pursued by UIN Sunan Kalijaga Yogyakarta by providing training to prepare an accessible learning platform for students with disabilities. The teaching platform used by lecturers was already accessible for students with deaf-speech disabilities in the 2020/2021 odd semester. (3) The integration is marked by the Rector of UIN Sunan Kalijaga to issue policies in implementing safe, comfortable and accessible online lectures for all students without any exception also for deaf-speech students. (4) Pattern maintenance: at this stage, there has not been a pattern that is able to motivate students with deaf-speech disabilities. All students are bored and decreased their motivation to study online.

\section{Acknowledgements}

This research is limited to the deaf and speech-disabled students at UIN Sunan Kalijaga. This research is conducted online with indepentent funding by using google forms and whattsapp. The deaf and speech-disabled students are willing to be the informant of this 
research.

\section{References}

[1] Amalia, Andina, and Nurus Sa'adah. 2020. "Dampak Wabah Covid-19 Terhadap Kegiatan Belajar Mengajar Di Indonesia.” Jurnal Psikologi 13(2):214-25. doi: 10.35760/psi.2020.v13i2.3572.

[2] Atsani, KH. Lalu Gede Muhammad Zainuddin. 2020. “Transformasi Media Pembelajaran Pada Masa Pandemi Covid-19 (Transformation of Learning Media during Covid-19 Pandemic).” Al-Hikmah: Jurnal Studi Islam 1(1):82-93.

[3] Basar, Afip Miftahul. 2021. "Problematika Pembelajaran Jarak Jauh Pada Masa Pandemi Covid-19." Edunesia: Jurnal Ilmiah Pendidikan 2(1):208-18. doi: 10.51276/edu.v2i1.112.

[4] Bjekić, Dragana, Svetlana Obradović, Milica Vučetić, and Milevica Bojović. 2014. "ETeacher in Inclusive e-Education for Students with Specific Learning Disabilities." Procedia - Social and Behavioral Sciences 128:128-33. doi: 10.1016/j.sbspro.2014.03.131.

[5] BNBP. 2012. "Kepala Badan Nasional Penanggulangan Bencana Tentang Daftar Isi Kepala Badan Nasional Penanggulangan Bencana Tahun 2012 Tentang Pedoman Umum Pengkajian Risiko 2 . Lampiran Peraturan.”

[6] Bruinen de Bruin, Yuri, Anne Sophie Lequarre, Josephine McCourt, Peter Clevestig, Filippo Pigazzani, Maryam Zare Jeddi, Claudio Colosio, and Margarida Goulart. 2020. "Initial Impacts of Global Risk Mitigation Measures Taken during the Combatting of the COVID-19 Pandemic." Safety Science 128(April):104773. doi: 10.1016/j.ssci.2020.104773.

[7] Burgstahler, Sheryl. 2021. "What Higher Education Learned About the Accessibility of Online Opportunities During a Pandemic What Higher Education Learned About the Accessibility of Online Opportunities During a Pandemic.” (August).

[8] Cahyani, Adhetya, Iin Diah Listiana, and Sari Puteri Deta Larasati. 2020. "Motivasi Belajar Siswa SMA Pada Pembelajaran Daring Di Masa Pandemi Covid-19." IQ (Ilmu Al-Qur'an): Jurnal Pendidikan Islam 3(01):123-40. doi: 10.37542/iq.v3i01.57.

[9] Creswell, John W. 2009. Research Design (Pendekatan Kualitatif, Kuantitatif, Dan Mix Method). Yogyakarta: Pustaka Pelajar.

[10] Dewi, Nurul Puspita. 2020. "Problematika Pembelajaran Untuk Anak Berkebutuhan Khusus Pada Masa Pandemi Covid-19 Di Sekolah.” JPI (Jurnal Pendidikan Inklusi) 4(1):1. doi: 10.26740/inklusi.v4n1.p1-10.

[11] Dewi, Wahyu Aji Fatma. 2020. "Dampak COVID-19 Terhadap Implementasi Pembelajaran Daring Di Sekolah Dasar.” Edukatif: Jurnal Ilmu Pendidikan 2(1):55-61. doi: 10.31004/edukatif.v2i1.89.

[12] Hamidaturrohmah, Hamidaturrohmah, and Tri Mulyani. 2020. "Strategi Pembelajaran Jarak Jauh Siswa Berkebutuhan Khusus Di Sd Inklusi Era Pandemi Covid-19.” ELEMENTARY: Islamic Teacher Journal 8(2):247. doi: 10.21043/elementary.v8i2.7907.

[13] Holmes, Emily A., Rory C. O’Connor, V. Hugh Perry, Irene Tracey, Simon Wessely, Louise Arseneault, Clive Ballard, Helen Christensen, Roxane Cohen Silver, Ian Everall, Tamsin Ford, Ann John, Thomas Kabir, Kate King, Ira Madan, Susan Michie, Andrew K. Przybylski, Roz Shafran, Angela Sweeney, Carol M. Worthman, Lucy 
Yardley, Katherine Cowan, Claire Cope, Matthew Hotopf, and Ed Bullmore. 2020. "Multidisciplinary Research Priorities for the COVID-19 Pandemic: A Call for Action for Mental Health Science." The Lancet Psychiatry 0366(20):1-14. doi: 10.1016/s2215-0366(20)30168-1.

[14] Holton, Robert J. 2015. "Talcott Parsons and the Theory of Economy and Society." Talcott Parsons on Economy and Society 25-106.

[15] Husein Fakhri et al. 2021. Pedoman Pembelajaran UIN Sunan Kalijaga Daring. 1st ed. Yogyakarta: Lembaga Penjaminan Mutu UIN Sunan Kalijaga.

[16] Kemenkes RI. 2020. "Pedoman Pencegahan Dan Pengendalian Coronavirus Disease (COVID-19)." Germas 0-115.

[17] Maftuhin, Arif. 2021. "COVID-19 Dan Pembelajaran Ramah Difabel Di Perguruan Tinggi." 2(2):1-10.

[18] Pratama, Rio Erwan, and Sri Mulyati. 2020. "Pembelajaran Daring Dan Luring Pada Masa Pandemi Covid-19.” Gagasan Pendidikan Indonesia 1(2):49. doi: 10.30870/gpi.v1i2.9405.

[19] Purwanto, Agus, Rudy Pramono, Masduki Asbari, Choi Chi Hyun, Laksmi, Mayesti Wijayanti, and and Ratna Setyowati Putri. 2020. "Studi Eksploratif Dampak Pandemi COVID-19 Terhadap Proses Pembelajaran Online Di Sekolah Dasar.” EduPsyCouns: Journal of Education, Psychology and Counseling 2(1):329-33.

[20] Pusat Layanan Difabel (PLD). 2021. Data Mahasiswa Difabel. Yogyakarta.

[21] Ro'fah, Ro'fah, Astri Hanjarwati, and Jamil Suprihatiningrum. 2020. Is Online Learning Accessible During COVID-19 Pandemic? Voices and Experiences of UIN Sunan Kalijaga Students with Disabilities. Vol. 14.

[22] Rohaniyah, J., A. Ainullah, F. Yuliawati, and ... 2021. "Pendampingan Pembelajaran Online Di Masa Pandemi Covid-19 Pada Siswa Dan Siswi MA Al-Jufri." GUYUB: Journal of ... 2(1):170-77. doi: 10.33650/guyub.v2i1.2123.

[23] Sciortino, Giuseppe. 2009. "Functionalism and Social Systems Theory." The New Blackwell Companion to Social Theory (December):106-23. doi: 10.1002/9781444304992.ch5.

[24] Tegar Tio, Ajiwan Ajiwan. 2020. Kuliah Online, Tantangan Dan Hambatannya Bagi Difabel. Yogyakarta, Indonesia.

[25] UNICEF. 2020. Pesan Dan Kegiatan Utama Pencegahan Dan Pengendalian COVID-19 Di Sekolah.

[26] Wardhani, Tsaniya Zahra Yuthika, and Hetty Krisnani. 2020. "Optimalisasi Peran Pengawasan Orang Tua Dalam Pelaksanaan Sekolah Online Di Masa Pandemi Covid19." Prosiding Penelitian Dan Pengabdian Kepada Masyarakat 7(1):48. doi: 10.24198/jppm.v7i1.28256.

[27] Williams, Vonetta M., Jenna M. Kahn, Matthew M. Harkenrider, Junzo Chino, Jonathan Chen, L. Christine Fang, Emily F. Dunn, Emma Fields, Jyoti S. Mayadev, Ramesh Rengan, Daniel Petereit, and Brandon A. Dyer. 2020. "COVID-19 Impact on Timing of Brachytherapy Treatment and Strategies for Risk Mitigation." Brachytherapy. doi: 10.1016/j.brachy.2020.04.005.

[28] Yuliana. 2020. "Corona Virus Diseases (Covid -19); Sebuah Tinjauan Literatur." Wellness and Healthy Magazine 2(1):187-92. 